\title{
Peningkatan Kapasitas dan Mutu Produk Brownies Tempe di Industri Rumah Tangga (IRT) "Browniesta" melalui Introduksi Teknologi Tepat Guna
}

\author{
Dwi Ishartani*, Windi Atmaka, Lia Umi Khasanah, Setyaningrum Ariviani dan Siswanti \\ Program Studi Ilmu Teknologi Pangan, Fakultas Pertanian, Universitas Sebelas Maret, Surakarta, Indonesia
}

Diterima: 25 November 2020; Disetujui: 17 April 2021

\begin{abstract}
Abstrak
Tempe merupakan produk pangan yang telah dikenal dunia sebagai superfood. Di Desa Pengkok, Kecamatan Kedawung, Kabupaten Sragen terdapat beberapa pengrajin tempe yang menyuplai tempe segar di seputar Kecamatan Kedawung. Selain itu tempe produksi daerah tersebut juga digunakan menjadi bahan baku brownies. Industri Rumah Tangga (IRT) yang memproduksi brownies berbahan baku tempe tersebut adalah IRT "BROWNIESTA". Produk brownies tempe sangat diminati konsumen, tetapi IRT "BROWNIESTA" belum bisa memenuhi permintaan karena keterbatasan jumlah oven. Selain itu kemasan, label, serta mutu produk yang dihasilkan belum stabil akibat rendahnya pemahaman tentang konsep Cara Produksi Pangan yang Baik (CPPOB). Oleh karena itu pada kegiatan pengabdian ini dilakukan introduksi teknologi tepat guna di IRT "BROWNIESTA" berupa: 1) introduksi oven berbahan bakar gas, 2) introduksi kemasan dan label, serta 3) pelatihan CPPOB sesuai pedoman BPOM. Mitra berpartisipasi aktif menyediakan bahan untuk uji coba oven yang diintroduksikan, menyediakan bahan dan sarana untuk evaluasi peningkatan mutu sensoris produk, serta memfasilitasi pelaksanaan pelatihan CPPOB. Berdasarkan hasil evaluasi, mutu sensoris brownies yang dihasilkan dengan menggunakan oven yang diintroduksikan mengalami peningkatan yang ditunjukkan dengan teksturnya yang lebih lembut serta crustnya yang halus dan tidak berkaramel. Produk juga terkemas dengan baik disertai informasi produk pada label yang tertempel di kemasan. Introduksi oven juga mampu meningkatkan kapasitas produksi sebesar 150\%. IRT "BROWNIESTA" menerapkan praktik produksi pangan yang lebih baik setelah mengikuti pelatihan CPPOB. Oleh karena itu dapat disimpulkan bahwa introduksi teknologi tepat guna di IRT "BROWNIESTA" mampu meningkatkan kapasitas dan mutu produk brownies tempe yang dihasilkan.
\end{abstract}

Kata kunci: brownies tempe; CPPOB; kapasitas produksi; mutu produk

\section{Improvement of Tempeh Brownies Production Capacity and Product Quality through Appropriate Technology Introduced to Small Medium Enterprise (SME) “Browniesta”}

\begin{abstract}
Tempeh had been recognized worldwide as a superfood. In Pengkok Village, Kedawung Sub-district, Sragen Regency, there were several traditional tempeh producers which supply fresh tempeh around Kedawung Sub-district. Tempeh produced in this area was also used as raw material for brownies production. "BROWNIESTA" is a Small Medium Enterprise (SME) which produces brownies made from tempeh. The demand of tempeh brownies was high, but it was difficult for SME "BROWNIESTA"

\footnotetext{
* Corresponding author: dwiishartani@staff.uns.ac.id

Cite this as: Ishartani, D., Atmaka, W., Khasanah, L. U., Ariviani, S., \& Siswanti. (2021). Peningkatan Kapasitas dan Mutu Produk Brownies Tempe di Industri Rumah Tangga (IRT) "Browniesta" melalui Introduksi Teknologi Tepat Guna. AgriHealth: Journal of Agri-food, Nutrition and Public Health, 2(1), 23-31. doi: http://dx.doi.org/ 10.20961/agrihealth.v2i1.45964
} 
to fulfill the demand due to the lack number of ovens. In addition, packaging, labels and the quality of the products had been unstable due to limited understanding of Good Manufacturing Practices (GMP) concept in food production. This community service introduced appropriate technology for SME "BROWNIESTA" in the form of: 1) introduction of gas-fired ovens, 2) introduction of packaging and labels and 3) GMP training according to BPOM guidelines. Partners actively participated in providing materials for the introduced oven trials, providing materials and tools for evaluation of product sensory quality improvement and facilitating the implementation of GMP training. Based on the evaluation results, the sensory quality of brownies produced using the introduced oven had increased as indicated by its softer texture and smoother crust that is not caramelized. The product was also packaged properly with product information on the label attached to the packaging. Oven introduction also increased the production capacity up to 150\%. SME "BROWNIESTA" implemented better food production practices after completing GMP training. Therefore, it could be concluded that the introduction of appropriate technology in SME "BROWNIESTA" increase the capacity and quality of the tempeh brownies products.

Keywords: GMP; product quality; production capacity; tempeh brownies

\section{PENDAHULUAN}

Tempe merupakan bahan makanan yang diolah melalui proses fermentasi atau pemeraman biji kedelai oleh jamur Rhizopus sp. Fermentasi adalah satu bentuk pengolahan pangan yang memiliki kemampuan meningkatkan sifat nutrisi dan fungsional dari suatu bahan. Fermentasi dilakukan untuk meningkatkan bioavailabilitas gizi (Ross et al., 2002). Selama fermentasi tempe, terjadi perubahan sifat fisiko-kimia yang meliputi perubahan tekstur kedelai dan tumbuhnya hifa kapang di permukaan kedelai (Hidayat et al., 2006). Selain itu di beberapa penelitian lain menyebutkan melalui fermentasi tempe dapat mendegradasi senyawa antinutrisi dan alergen dari kedelai (Song et al., 2008). Selama fermentasi kedelai menjadi tempe terjadi juga peningkatan daya cerna tempe. Peningkatan ini terjadi karena reduksi senyawa antrinutrisi tanin dan asam fitat dengan cara memproduksi asam yang dapat menghambat produksi bakteri patogen (Babu et al., 2009). Oleh karena itu tempe sering disebut sebagai superfood.

Tempe merupakan makanan asli Indonesia, khususnya Jawa. Oleh karena itu pengrajin tempe banyak ditemukan di Jawa, di antaranya di Desa Pengkok, Kecamatan Kedawung, Kabupaten Sragen. Tempe produksi Desa Pengkok umumnya didistribusikan dalam bentuk tempe segar di seputar Kecamatan Kedawung. Selain dijual dalam bentuk produk segar, tempe produksi daerah tersebut juga telah diolah menjadi brownies tempe.
Sesuai dengan namanya brownies adalah kue yang memiliki warna cokelat yang gelap. Brownies merupakan kue yang pada awalnya terbuat dari adonan yang gagal dan keras (bantat). Inovasi dan kreasi pembuatan brownies sekarang ini banyak dimulai dengan mensubstitusi tepung terigu sebagai bahan baku brownies. Substitusi bahan tambahan pada pembuatan brownies ini juga diarahkan untuk menciptakan pangan yang dapat memenuhi kebutuhan gizi dan bermanfaat untuk kesehatan. Hasil penelitian Latifah (2019) menunjukkan bahwa tempe segar mampu mensubstitusi terigu hingga 50\% pada pembuatan brownies dengan karakteristik sensoris yang disukai oleh konsumen.

Produsen brownies tempe sekaligus mitra yang digandeng pada kegiatan ini adalah Industri Rumah Tangga (IRT) "BROWNIESTA". Usaha ini didirikan oleh Aprilia Evi Lathifah, seorang alumni D3 THP, yang terinspirasi dengan topik Tugas Akhir yang diambilnya. IRT ini berlokasi di Desa Pengkok RT 01 RW 03, Kecamatan Kedawung, Kabupaten Sragen. Usaha ini memiliki tiga orang karyawan. Produk brownies tempe yang dihasilkan IRT ini awalnya terdengar sedikit aneh, karena ada penambahan bahan tempe (pasta tempe) pada adonannya. Namun setelah mencoba, konsumen menyukainya karena rasanya enak dan bergizi. Selain itu, biji kedelai pada tempe yang masih utuh membuat brownies tempe seperti ditambah biji kacang almond.

Sejak memulai usaha IRT "BROWNIESTA" memproduksi brownies berdasarkan pesanan. IRT "BROWNIESTA" hanya berani melayani pesanan sebanyak 12 pak per hari karena kendala 
teknologi produksi. Hal ini sangat disayangkan karena sebenarnya permintaan pesanan brownies tempe dari konsumen cukup tinggi. IRT "BROWNIESTA" beberapa kali menerima pesanan di atas 20 pak per hari tetapi terpaksa menolaknya. Hal ini disebabkan proses pemanggangan brownies tempe masih menggunakan oven kompor yang hanya mampu menampung 6 loyang batch ${ }^{-1}$ dengan waktu pemanggangan 1,5 jam batch ${ }^{-1}$. Dengan waktu proses pra pemanggangan mencapai 1 jam dan pendinginan pasca pemanggangan 0,5 jam, maka total waktu produksi brownies adalah 3 jam batch $^{-1}$. Oleh karena itu, IRT Brownies Tempe "BROWNIESTA" hanya mampu berproduksi 2 batch hari ${ }^{-1}$ atau setara dengan 12 pak hari ${ }^{-1}$. Artinya, proses produksi brownies tempe di IRT Brownies Tempe "BROWNIESTA" sangat tidak efisien sehingga mengakibatkan kapasitas produksinya rendah. Dokumentasi Proses pemanggangan brownies tempe dapat dilihat pada Gambar 1.

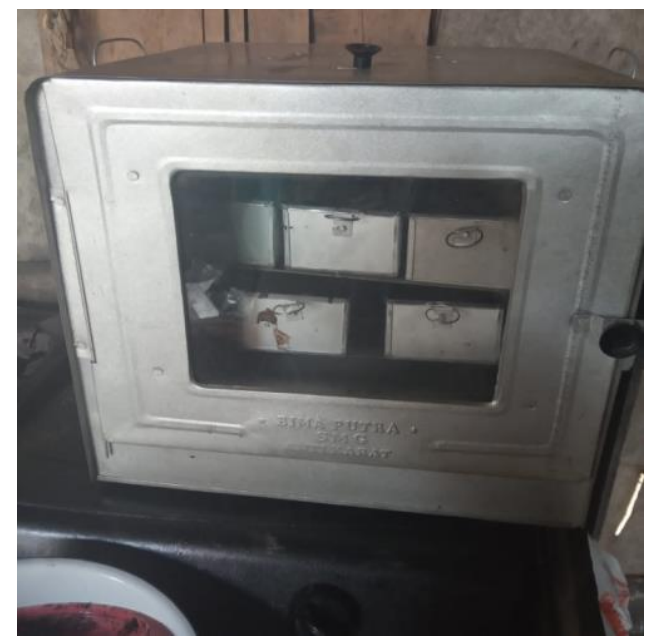

Gambar 1. Proses pemanggangan brownies tempe menggunakan satu oven kompor sehingga kapasitasnya rendah

Selain kapasitas produksi yang rendah, mutu produk brownies yang dihasilkan juga belum konsisten. Hal ini ditandai dengan tingkat kehalusan pasta tempe yang beragam sehingga tekstur brownies tidak konsisten pada setiap batch produksi yang berbeda. Rendahnya pemahaman IRT terhadap Cara Produksi Pangan Olahan yang Baik (CPPOB), yaitu pedoman yang menjelaskan cara memproduksi pangan agar bermutu, aman dan layak untuk dikonsumsi menjadi pemicu permasalahan ini. CPPOB merupakan salah satu faktor penting untuk memenuhi standar mutu atau persyaratan keamanan pangan yang ditetapkan BPOM RI untuk pangan. Penerapan CPPOB dalam suatu industri pangan akan lebih menjamin keberlangsungan usaha pangan tersebut, karena dapat memberikan rasa aman konsumen terhadap pangan yang dikonsumsi. Selain itu, penerapan CPPOB dalam industri pangan juga dapat berperan dalam pembangunan citra suatu usaha, meminimalkan kerusakan produk dan meminimalkan biaya penarikan produk. Saat ini IRT "BROWNIESTA" belum sepenuhnya memahami dan menerapkan prinsip CPPOB. Contoh belum dipahami dan diterapkannya CPPOB pada proses produksi brownies tempe di IRT ini dapat dilihat pada Gambar 2.

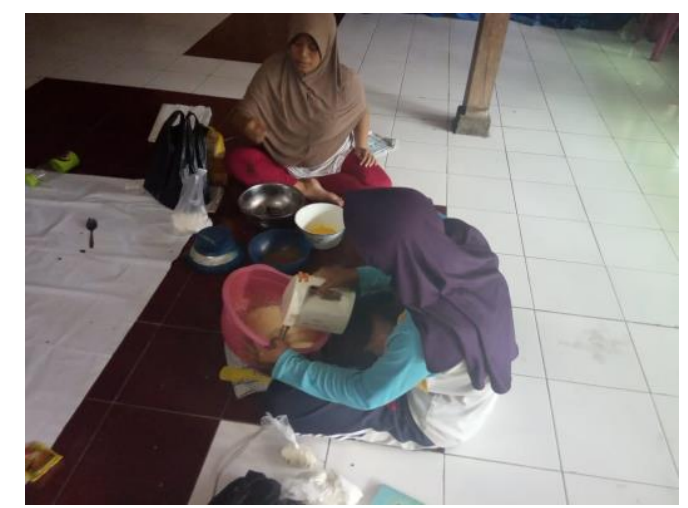

Gambar 2. Proses pembuatan adonan brownies tempe yang dilakukan di atas lantai langsung menunjukkan belum dipahami dan diterapkannya CPPOB

Pemahaman yang rendah IRT terhadap konsep CPPOB juga dapat dilihat dari kemasan yang digunakan dan belum digunakannya label. Kemasan yang digunakan telah sesuai dengan karakteristik produk dan peraturan, tetapi bentuk dan ukurannya belum konsisten. Belum digunakannya label membuat produsen kesulitan memperkuat citra produk sekaligus membuat konsumen kesulitan memperoleh informasi tentang produk brownies tempe yang diproduksi IRT "BROWNIESTA".

Oleh karena itu kegiatan pengabdian ini bertujuan meningkatkan efisiensi dan kapasitas produksi brownies tempe melalui introduksi oven berbahan bakar gas. Selain itu kegiatan pengabdian juga bertujuan meningkatkan 
pemahaman IRT tentang CPPOB melalui pelatihan CPPOB sehingga diharapkan IRT secara konsisten mampu menghasilkan produk yang berkualitas dan aman.

\section{BAHAN DAN METODE}

\section{Tempat dan waktu pelaksanaan}

Kegiatan pengabdian ini dilaksanakan di tempat IRT "BROWNIESTA", yaitu Desa Pengkok RT 01 RW 03, Kecamatan Kedawung, Kabupaten Sragen, Provinsi Jawa Tengah. Kegiatan pengabdian berlangsung pada bulan Juli hingga November 2020.

\section{Jenis kegiatan}

Introduksi oven dengan bahan bakar gas

Oven yang diintroduksikan pada kegiatan pengabdian ini adalah oven gas portabel. Kegiatan introduksi oven meliputi pengenalan cara kerja, cara perawatan dan pemeliharaan oven yang diintroduksikan dan praktik langsung penggunaan oven yang diintroduksikan untuk pemanggangan brownies tempe produksi IRT mitra. Pada kegiatan ini partisipasi mitra ditunjukkan dengan penyediaan bahan - bahan maupun sarana untuk praktik penggunaan oven.

\section{Introduksi kemasan dan label}

Kemasan yang diintroduksikan pada mitra adalah kemasan brownies berbahan plastik berwarna cokelat untuk wadahnya dan bening untuk tutupnya dengan sealer berupa selotip bening yang disiapkan secara terpisah. Kemasan ini dilengkapi dengan label stiker yang dicetak terpisah sehingga praktis penggunaannya dan fleksibel pemesanannya. Desain label merupakan hasil diskusi antara tim pengabdi dengan IRT mitra.

\section{Pelatihan $C P P O B$}

Kegiatan pelatihan CPPOB ini difasilitasi oleh IRT mitra sebagai bentuk partisipasi mitra dalam pelaksanaan kegiatan pengabdian ini. Materi CPPOB yang dilatihkan sesuai dengan Perka BPOM RI NOMOR HK.03.1. 23.04.12.2206 Tahun 2012 yang meliputi: 1) Lokasi dan lingkungan produksi, 2) Peralatan produksi, 3) Suplai air atau sarana penyediaan air, 4) Fasilitas dan kegiatan higiene dan sanitasi, 5) Kesehatan dan higiene Karyawan, 6) Pemeliharaan dan program higiene sanitasi karyawan, 7) Penyimpanan, 8) Pengendalian proses, 9) Pelabelan pangan, 10) Pengawasan oleh penanggungjawab, 11) Penarikan produk,
12) Pencatatan dan dokumentasi dan 11) Pelatihan karyawan.

\section{Monitoring kegiatan}

Monitoring dilaksanakan 3 bulan setelah kegiatan introduksi oven berbahan bakar gas, introduksi kemasan dan label, serta pelatihan CPPOB. Kegiatan monitoring dilaksanakan secara daring melalui platform Zoom Meeting dan diikuti oleh pemilik IRT "BROWNIESTA" serta seluruh anggota tim pengabdian. Monitoring secara daring dipilih karena kegiatan ini dilaksanakan pada masa pandemi COVID-19.

\section{Evaluasi kegiatan}

Evaluasi kegiatan yang dilakukan meliputi: 1) evaluasi terhadap perubahan kualitas sensoris produk brownies tempe yang dihasilkan menggunakan oven lama dan menggunakan oven yang diintroduksikan, 2) evaluasi perubahan efisiensi dan kapasitas produksi sebelum dan sesudah introduksi oven berbahan bakar gas portabel, 3) evaluasi perubahan mutu produk sebelum dan sesudah introduksi kemasan dan label, serta 4) evaluasi penerapan СРPOB oleh mitra.

\section{HASIL DAN PEMBAHASAN}

Kegiatan pengabdian ini dimulai dengan koordinasi dan sosialisasi rencana kegiatan pengabdian. Hal ini diperlukan untuk mencocokkan kondisi terkini mitra terkait kendala dan permasalahan yang dihadapi mitra, yaitu apakah masih sama dengan kondisi saat survei sebelumnya. Informasi ini penting untuk desain kegiatan pengabdian yang tepat sehingga kebermanfaatan dari kegiatan pengabdian ini lebih bisa dirasakan untuk menjawab kebutuhan mitra. Terlebih lagi, kegiatan ini dilaksanakan di masa pandemi COVID-19 yang diduga mempengaruhi jalannya usaha mitra. Gambar 3 menunjukkan kegiatan koordinasi dan sosialisasi rencana kegiatan pengabdian bagi mitra IRT "BROWNIESTA".

Peningkatan mutu produk dan kapasitas produksi brownies tempe melalui introduksi oven gas portabel

Mitra IRT "BROWNIESTA" telah memperoleh tambahan alat produksi yang memenuhi syarat untuk produksi pangan yang baik, yaitu oven gas portabel beserta regulator dan tabung gas, yang dilengkapi 
dengan penunjuk suhu dan pengatur udara pada bagian atas. Gambar 4 memperlihatkan pelaksanaan kegiatan introduksi oven, kemasan dan label di mitra IRT "BROWNIESTA" dan Gambar 5 memperlihatkan oven yang diintroduksikan dapat bekerja dengan baik.
Penggunaan gas sebagai bahan bakar oven dinilai menguntungkan karena di Indonesia biaya energi yang dibutuhkan lebih rendah dibandingkan dengan oven listrik. Hal ini berbeda dengan yang terjadi di Uni Eropa (ETN, 2012).

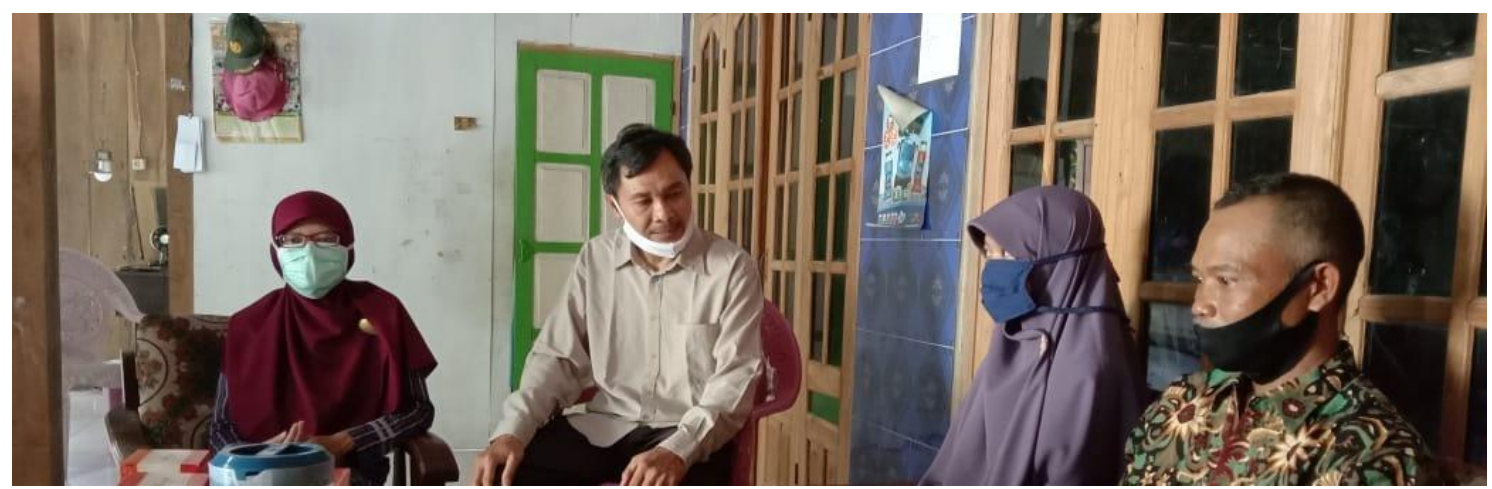

Gambar 3. Koordinasi dan sosialisasi rencana kegiatan pengabdian di IRT "BROWNIESTA" yang dilaksanakan pada masa pandemi COVID-19

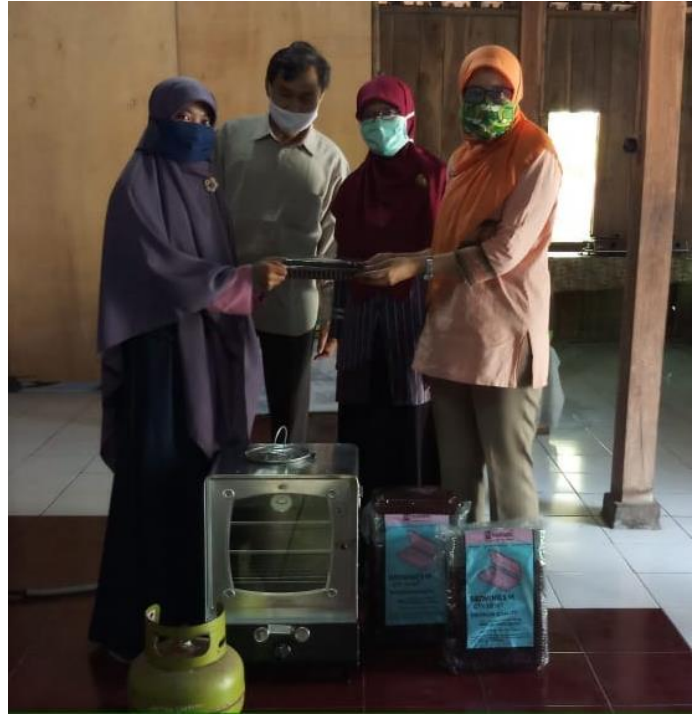

Gambar 4. Introduksi oven gas portabel beserta kelengkapannya, kemasan brownies dan label

Hasil evaluasi menunjukkan penggunaan oven gas portabel di IRT "BROWNIESTA" mampu meningkatkan mutu produk sekaligus kapasitas produksi brownies tempe. Oven gas portabel mampu menghasilkan panas yang lebih merata sehingga mutu produk brownies lebih seragam dan teksturnya lebih baik. Brownies yang dihasilkan sebelum introduksi oven gas portabel memiliki tekstur (crumb) yang lebih bantat dan padat dengan crust yang lebih tebal dan berkaramel. Akibatnya bagian yang memiliki crust yang tebal dan

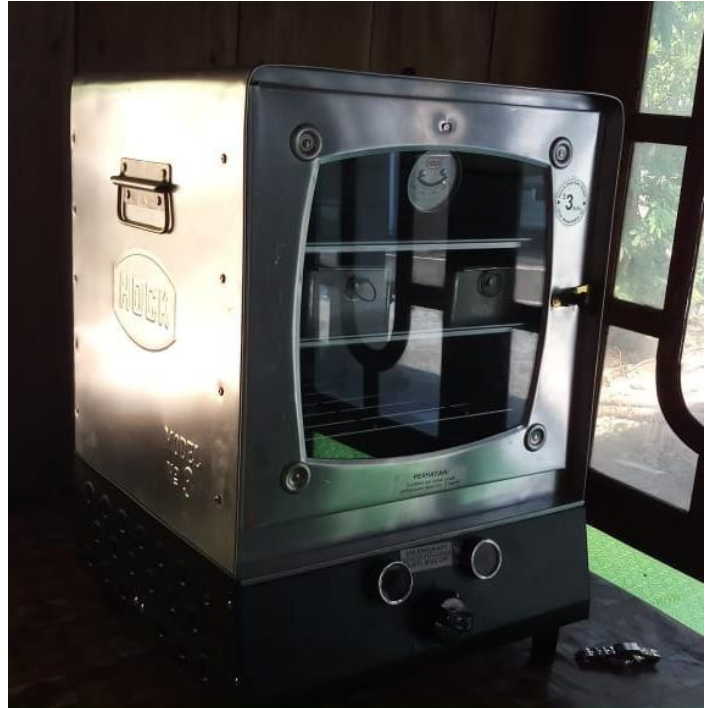

$$
\begin{array}{llrr}
\text { Gambar 5. Oven gas } & \text { portabel } & \begin{array}{r}
\text { yang } \\
\text { diintroduksikan } \\
\text { dengan baik }
\end{array} & \text { bekerja }
\end{array}
$$

berkaramel tersebut harus dibuang sehingga ukuran brownies menjadi lebih kecil serta menyisakan limbah crust yang tidak memiliki nilai ekonomis. Sedangkan brownies yang dihasilkan setelah menggunakan oven gas portabel yang diintroduksikan memiliki crumb yang lebih lembut dan berpori serta tidak ada crust yang tebal dan berkaramel sehingga ukuran brownies yang dikemas menjadi lebih besar. Crumb dan crust terbentuk selama proses pemanggangan produk bakery, dimana adonan yang tergelatinisasi akan membentuk 
film yang elastis dan berpori. Struktur elastis di bagian dalam disebut crumb sedangkan struktur elastis di permukaan yang lebih keras karena kehilangan kelembaban selama pemanggangan disebut crust (Vanin et al., 2009). Ketampakan brownies tempe produksi IRT "BROWNIESTA" sebelum dan sesudah introduksi oven gas portabel dapat dilihat pada Gambar 6.

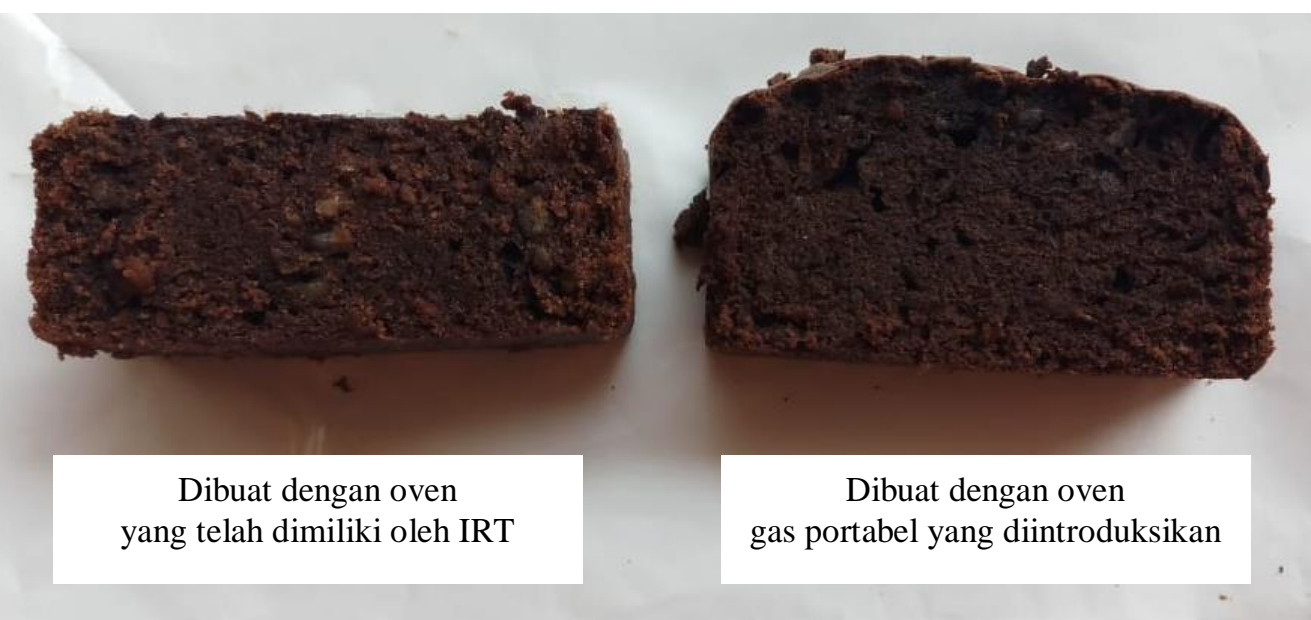

Gambar 6. Ketampakan brownies tempe yang dipotong melintang menunjukkan perbaikan crumb, crust, dan ukuran setelah introduksi oven gas portabel

Selain panas yang lebih merata, pengoperasian oven gas portabel juga dirasakan lebih mudah oleh mitra. Oleh karena itu, saat ini mitra lebih memilih menggunakan oven gas portabel yang diintroduksikan oleh tim pengabdian. Oven gas portabel mampu meningkatkan kapasitas produksi brownies tempe di IRT "BROWNIESTA" dari 12 pak hari-1 menjadi 18 pak hari $^{-1}$, atau meningkat sebesar $150 \%$. Namun demikian, pada masa pandemi COVID -19 permintaan brownies tempe mengalami penurunan, bahkan IRT "BROWNIESTA" sempat berhenti berproduksi sementara. Dengan dukungan dan dorongan serta solusi terkait pemasaran yang diberikan selama pelaksanaan pengabdian, sekarang ini mitra IRT telah kembali menerima pesanan dan memproduksi brownies tempe.

Sejak bulan September 2020 mitra mulai berproduksi kembali secara kontinyu dengan varian produk yang semakin beragam untuk semakin menarik minat konsumen. Varian produk tersebut meliputi brownies tempe original, brownies tempe dengan topping cokelat meses, brownies tempe dengan topping cokelat ungu, bolu pisang dan bolu ubi ungu yang masing-masing dijual dengan harga Rp20.000 pak $^{-1}$. Kapasitas produksi per pekan untuk masing-masing varian tersebut adalah brownies tempe 4-5 pak, bolu pisang 8-10 pak dan bolu ubi ungu 15-17 produk.
Peningkatan mutu tampilan produk dan keamanan brownies tempe melalui introduksi kemasan dan label

UKM yang mengolah produk pangan sering menghadapi kendala utama dalam hal pengemasan. Padahal, kemasan merupakan hal penting yang menjadi kunci dalam pemasaran, yaitu menjadikan produk lebih marketable sekaligus meningkat nilai jualnya (Anwar dan Gunarsa, 2011). Introduksi kemasan dan label pada produk brownies tempe produksi IRT "BROWNIESTA" mampu meningkatkan tampilan dan keamanan produk sehingga diharapkan produk dapat dipasarkan dengan jangkauan lebih luas. Kemasan yang diintroduksikan adalah kemasan plastik polyethylene sekali pakai dengan warna cokelat gelap di bagian wadah bawah dan warna putih bening di bagian tutup atas. Kemasan ini merupakan kemasan yang umum digunakan untuk mengemas produk brownies dan aman. Kemasan ini kemudian diseal menggunakan selotip plastik transparan sehingga meminimalkan kontaminasi produk dan diharapkan produk lebih aman.

Label kemasan yang diintroduksikan berupa stiker berbahan laminat kertas dan plastik. Desain kemasan merupakan hasil diskusi IRT mitra dengan tim pengabdi sehingga label produk yang dihasilkan selain memiliki nilai estetika dan sesuai dengan citra produk yang 
dibentuk IRT, juga memenuhi peraturan. Peraturan tentang kemasan dan label pangan secara rinci telah diatur dalam Peraturan BPOM (BPOM, 2011; BPOM, 2018). Kemasan dan label produk brownies tempe hasil introduksi dapat dilihat pada Gambar 7.
Peningkatan tampilan dan mutu produk IRT dan UKM dengan adanya introduksi kemasan dan label juga telah dilaporkan oleh Nursiwi et al. (2019) pada produk sosis solo dan Parnanto et al. (2017) pada produk tahu pong.

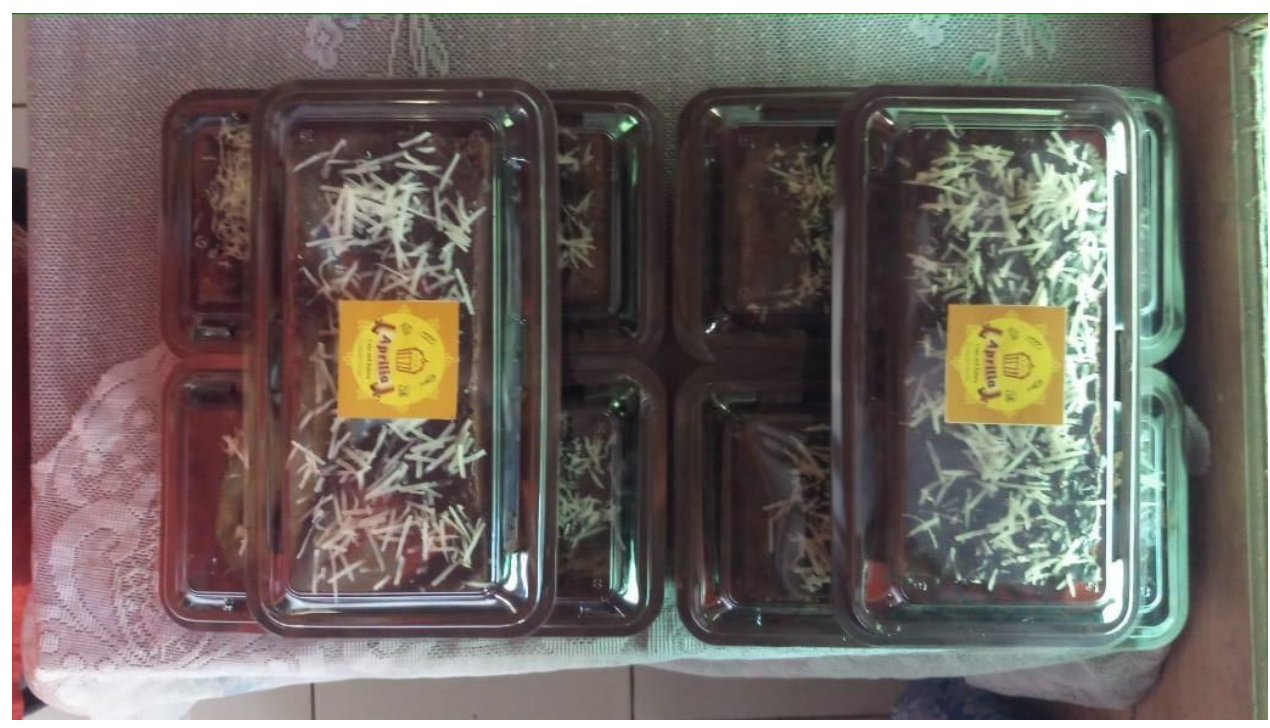

Gambar 7. Tampilan produk brownies tempe IRT "BROWNIESTA" menggunakan kemasan dan label yang diintroduksikan

\section{Penerapan CPPOB-IRT}

Pelatihan CPPB-IRT dilakukan dengan memberikan tentang gambaran bagaimana cara produksi pangan yang baik bagi industri rumah tangga sesuai Keputusan Kepala BPOM Republik Indonesia Nomor HK.03.1.23.04.12.2206 tahun 2012 supaya

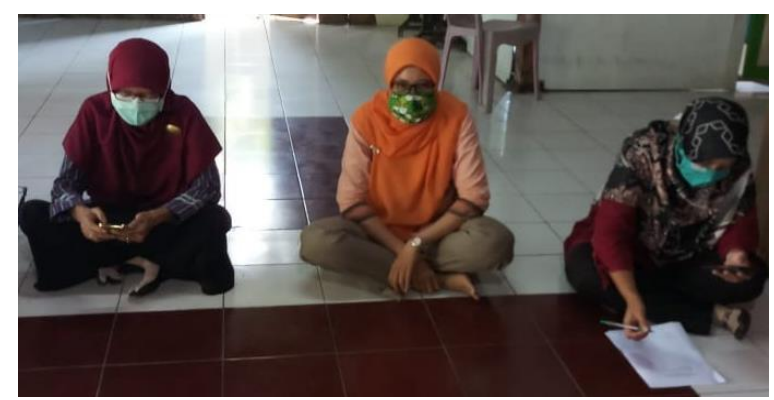

a. industri pangan dapat menghasilkan produk pangan yang aman dan bermutu sesuai dengan tuntutan konsumen baik konsumen domestik maupun internasional. Suasana pelatihan CPPOB-IRT yang diikuti oleh pemimpin dan pekerja IRT "BROWNIESTA" disajikan pada Gambar 8.

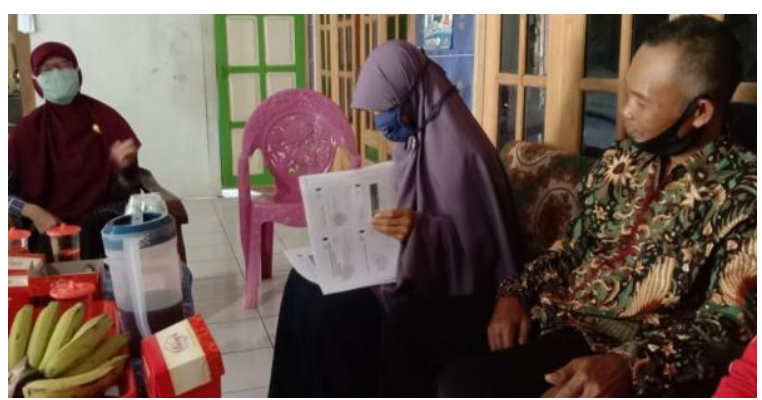

b.

Gambar 8. Suasana pelatihan CPPOB IRT (a) Peserta pelatihan memperhatikan pemateri menyampaikan makalah dan (b) IRT "BROWNIESTA" mendiskusikan penerapan CPPOB IRT dengan tim pengabdi

Hasil monitoring dan evaluasi secara daring (Gambar 9) menunjukkan IRT "BROWNIESTA sudah melaksanakan CPPOBIRT yang telah dilatihkan (Tabel 1). Hal ini dapat dilihat dari penimbangan bahan secara lebih teliti, penggunaan masker oleh pekerja, pelaksanaan proses produksi di atas meja yang bersih, penerapan SOP (Standard Operation Procedures), serta sudah menggunakan label kemasan dalam produksi brownies tempe. 


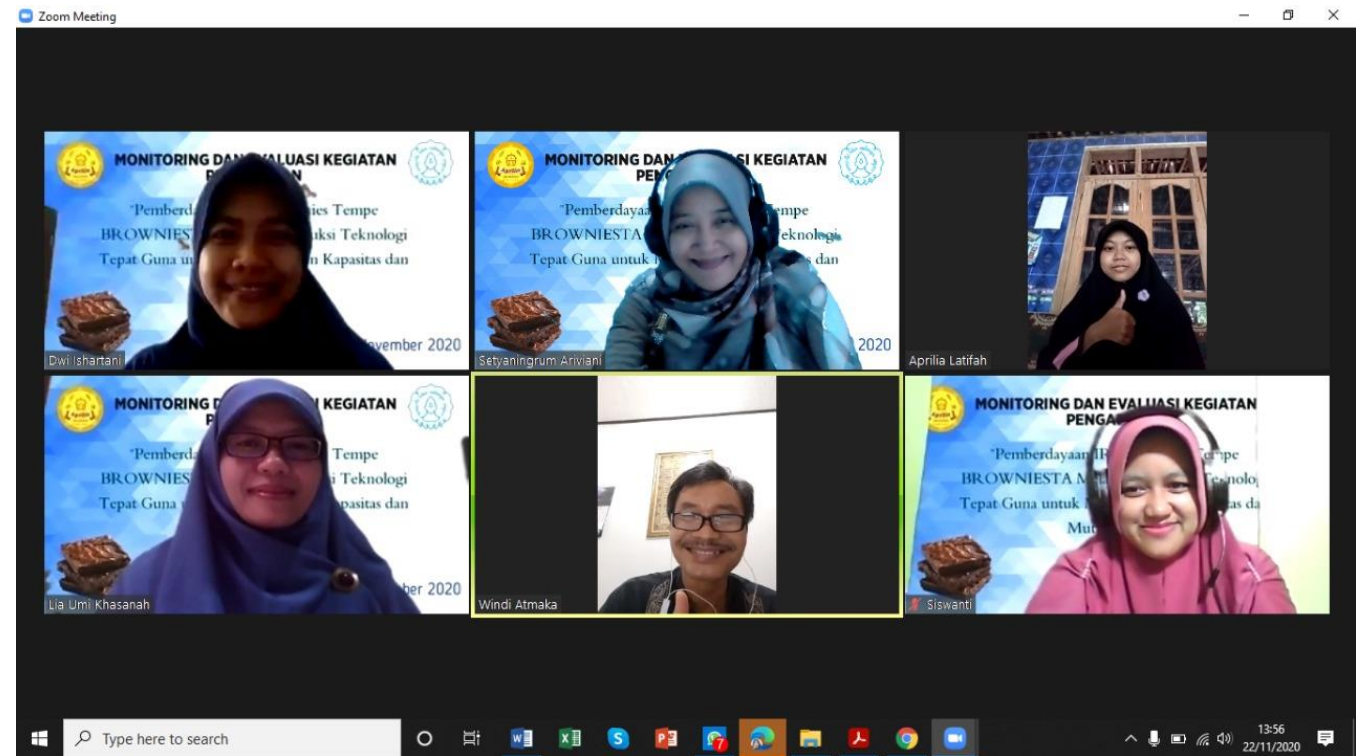

Gambar 9. Monitoring dan evaluasi kegiatan secara daring diikuti oleh mitra dan tim pengabdian

Tabel 1. Hasil evaluasi penerapan CPPOB-IRT oleh IRT "BROWNIESTA"

\begin{tabular}{|c|c|c|c|}
\hline No. & Kriteria CPPOB-IRT & Sebelum pelatihan & Setelah pelatihan \\
\hline 1. & $\begin{array}{l}\text { Lokasi dan lingkungan } \\
\text { produksi }\end{array}$ & $\begin{array}{l}\text { Bersih, jauh dari sampah, } \\
\text { pembersihan } \\
\text { secara rutin }\end{array}$ & $\begin{array}{l}\text { Bersih, jauh dari sampah, } \\
\text { pembersihan } \\
\text { secara rutin }\end{array}$ \\
\hline 2. & $\begin{array}{l}\text { Bangunan dan fasilitas } \\
\text { produksi }\end{array}$ & Dilakukan di atas lantai langsung & $\begin{array}{l}\text { Dilakukan di atas bangku kerja } \\
\text { yang bersih }\end{array}$ \\
\hline 3. & Peralatan produksi & Bersih dan food grade & Bersih dan food grade \\
\hline 4. & $\begin{array}{l}\text { Suplai air dan } \\
\text { penyediaan air }\end{array}$ & $\begin{array}{l}\text { Air sumur yang tidak berwarna, } \\
\text { tidak berbau, tidak berasa }\end{array}$ & $\begin{array}{l}\text { Air sumur yang tidak berwarna, } \\
\text { tidak berbau, tidak berasa }\end{array}$ \\
\hline 5. & $\begin{array}{l}\text { Fasilitas dan kegiatan } \\
\text { hygiene dan sanitasi }\end{array}$ & $\begin{array}{l}\text { Mencukupi dan dilakukan secara } \\
\text { benar dan tepat }\end{array}$ & $\begin{array}{l}\text { Mencukupi dan dilakukan secara } \\
\text { benar dan tepat }\end{array}$ \\
\hline 6. & $\begin{array}{l}\text { Kesehatan dan hygiene } \\
\text { karyawan }\end{array}$ & $\begin{array}{l}\text { Hanya yang sehat yang bekerja } \\
\text { dan pekerja belum mengenakan } \\
\text { masker selama bekerja }\end{array}$ & $\begin{array}{l}\text { Hanya yang sehat yang bekerja } \\
\text { dan pekerja mengenakan masker } \\
\text { selama bekerja }\end{array}$ \\
\hline 7. & Pengendalian produksi & $\begin{array}{l}\text { a. Beberapa bahan ditimbang } \\
\text { menggunakan perkiraan }\end{array}$ & $\begin{array}{l}\text { a. Seluruh bahan ditimbang } \\
\text { secara teliti }\end{array}$ \\
\hline & & b. Belum ada SOP produksi & b. Sudah ada SOP produksi \\
\hline 8. & Pelabelan pangan & Belum ada label pada kemasan & label pada kemasan \\
\hline
\end{tabular}

\section{KESIMPULAN}

Berdasarkan evaluasi yang telah dilakukan dapat disimpulkan bahwa introduksi oven gas portabel, kemasan dan label dalam kegiatan pengabdian ini telah meningkatkan mutu produk maupun kapasitas produksi brownies tempe yang dihasilkan oleh mitra IRT "BROWNIESTA". Selain itu materi pelatihan CPPOB juga telah sebagian besar diterapkan oleh mitra.

\section{UCAPAN TERIMA KASIH}

Terima kasih kepada tim Research Group (RG) Food Product Development atas terselenggaranya Pengabdian Mandiri UNS tahun 2020 dengan nomor kontrak 125/ UN27.21/HK/2020.

\section{DAFTAR PUSTAKA}

Anwar, Y., \& Gunarsa, D. (2011). Cerdas Mengemas produk makanan \& minuman. 
Jakarta: PT AgroMedia Pustaka. Tersedia dari https://scholar.google.co.id/scholar?q=Cerdas +Mengemas+Produk+Makanan+\%26+Minu man\&hl=id\&authuser=3

Babu, P. D., Bhakyaraj, R., \& Vidhyalakhmi, R. (2009). A low cost nutritious food "tempeh"- a review. World Journal of Dairy and Food Sciences, 4(1), 22-27. Tersedia dari http:// www.idosi.org/wjdfs/wjdfs4(1)/5.pdf

BPOM [Badan Pengawas Obat dan Makanan Republik Indonesia]. (2011). Peraturan Kepala Badan Pengawas Obat dan Makanan Republik Indonesia Nomor HK.03.1.23.07. 11.6664 Tahun 2011 tentang Pengawasan Kemasan Pangan. Tersedia dari https:// aspadin.com/uploads/1/0/2/3/102373556/per_ ka_bpom_2011_pengawasan_kemasan_panga n_--_perubahan_di_2014.pdf

BPOM [Badan Pengawas Obat dan Makanan Republik Indonesia]. (2012). Peraturan Kepala Badan Pengawas Obat dan Makanan Republik Indonesia Nomor HK.03.1.23.04. 12.2206 Tahun 2012 tentang Cara Produksi Pangan yang Baik untuk Industri Rumah Tangga. Tersedia dari https://standarpangan. pom.go.id/dokumen/peraturan/2012/Perka_B

POM_No_HK.03.1.23.04.12.2206_Tahun_20 12_tentang_CPPB_PIRT.pdf

BPOM [Badan Pengawas Obat dan Makanan Republik Indonesia]. (2018). Peraturan Badan Pengawas Obat dan Makanan Nomor 31 Tahun 2018 tentang Label Pangan Olahan. Tersedia dari https://standarpangan.pom.go. id/dokumen/peraturan/2018/0._PerBPOM_31 _Tahun_2018_Label_Pangan_Olahan_31_Jan _2019_Join.pdf

ETN [Energy Technology Network]. (2012). Cooking appliances. IEA ETSAP Technology Brief R06, 1-8. Tersedia dari https://iea-etsap.org/E-TechDS/PDF/R06_Co oking_FINAL_GSOK.pdf
Hidayat, N., Padaga, M. C., \& Suhartini, S. (2006). Mikrobiologi industri. Yogyakarta: C.V Andi Offset. Tersedia dari https:// scholar.google.co.id/scholar?hl=id\&as_sdt=0, $5 \&$ cluster $=13315572710943880237$

Latifah, A. E. (2019). Praktik produksi brownies dengan substitusi tempe. Laporan Tugas Akhir Prodi D3 THP. Fakultas Pertanian Universitas Sebelas Maret. Surakarta. Tersedia dari https: //digilib.uns.ac.id/dokumen/download/71108/ MzYxNjk0/Praktek-produksi-brownies-tempe -Mat-Brow-depan_1.pdf

Nursiwi, A., Ishartani, D., Siswanti, \& Sari, A. M. (2019). Perbaikan kemasan untuk meningkatkan nilai jual sosis Solo di UKM Sosis Gajahan. Jurnal Sinergitas PkM \& CSR, 4(1), 75-85. Tersedia dari https://ojs.uph.edu/ index.php/JSPC/article/view/2099

Parnanto, N. H. R., Khasanah, L. U., \& Ishartani, D. (2017). Perbaikan proses dan kemasan tahu pong produksi UKM Al Amin di Kecamatan Karangpandan Kabupaten Karanganyar. Prosiding Konferensi Nasional PkM-CSR Ke3, 248-256.

Ross, R. P., Morgan, S., \& Hil, C. (2002). Preservation and fermentation: past, present and future. International Journal of Food Microbiology, 79(1-2), 3-16. https://doi.org/ 10.1016/S0168-1605(02)00174-5

Song, Y.-S., Frias, J., Martinez-Villaluenga, C., Vidal-Valdeverde, C., \& Gonzalez de Mejia, E. (2008). Immuno reactivity reduction of soybean meal by fermentation, effect on amino acid composition and antigenicity of commercial soy products. Food Chemistry, 108(2), 571-581. https://doi.org/10.1016/ j.foodchem.2007.11.013

Vanin, F., Lucas, T., \& Trystram, G. (2009). Crust formation and its role during baking. Trends in Food Science and Technology, 20(8), 333343. https://doi.org/10.1016/j.tifs.2009.04.001 